\title{
ASYMMETRIC WETTED SECTOR ANGLE IN WATER DISTRIBUTION OF TRAVELING GUN IRRIGATION SYSTEMS
}

\author{
Giuliani do Prado ${ }^{*}$, Alberto Colombo
}

${ }^{1 *}$ Corresponding author. Universidade Estadual de Maringá/ Cidade Gaúcha - PR, Brazil.

E-mail: gprado@uem.br | ORCID ID: https://orcid.org/0000-0001-5442-7446

\section{KEYWORDS}

strip width, travel path, uniformity coefficient.

\begin{abstract}
This work aimed to simulate the water distribution of traveler gun irrigation, working with asymmetrical wetted angles and in windy conditions. In the simulations of a sprinkler with uniform radial profile, the following were considered: i) wetted angles between 180 and $330^{\circ}$; ii) wetted angle asymmetries from 0 to $90^{\circ}$; iii) wind speeds from 0 to $4.5 \mathrm{~m} \mathrm{~s}^{-1}$; and iv) wind direction of 0,45 , and $90^{\circ}$. Christiansen uniformity coefficients (CU) were calculated for strip widths from 30 to $100 \%$ of the sprinkler wetted diameter (WD). Regardless of the wetted angle adjustment, irrigations under wind speeds of $4.5 \mathrm{~m} \mathrm{~s}^{-1}$ should be avoided and strip spacings of less than 50\% WD provide high CU for wind speeds up to $3.0 \mathrm{~m} \mathrm{~s}^{-1}$. For any wind conditions, asymmetries in the wetted angle led to a reduction in $\mathrm{CU}$ for a wetted angle of $210^{\circ}$. In the range of wetted angle from 270 to $330^{\circ}$, asymmetric adjustments of up to $20^{\circ}$ provided a higher CU than $80 \%$ for a wind speed of $3 \mathrm{~m} \mathrm{~s}^{-1}$ and directions diagonal and perpendicular to the travel path associated with strip spacings between 60 to $70 \% \mathrm{WD}$, which are the spacings recommended by manufacturers of traveler irrigation machines.
\end{abstract}

\section{INTRODUCTION}

Traveling gun irrigation is a sprinkler system intensively used in sugarcane cultivation to apply water and vinasse (ANA, 2017). According to Silva et al. (2015) and Leda et al. (2019), this cultivation has high economic value for Brazilian agribusiness, allowing its use in the production of sugar, alcohol, and energy.

For irrigated crops to reach high production, irrigation systems must have satisfactory values of water application uniformity and an acceptable Christiansen uniformity coefficient of around 80\% (Darko et al., 2017). Low water application uniformity of irrigation systems is associated with a lack of specific sizing criteria capable of providing satisfactory performance under different operational conditions (Prado, 2016). Maosheng et al. (2018) pointed out that the technical information provided by sprinkler manufacturers is restricted to basic parameters of working pressure versus flow rate.

The water distribution of a gun sprinkler, which works in a traveler irrigation machine, is influenced by controllable factors (sprinkler type, nozzle diameter, working pressure, jet angle, wetted angle, and space between strips) and weather factors (wind speed and direction) (Oliveira et al., 2012). Silva et al. (2007) reported that traveling gun irrigation systems working with a large gun sprinkler are characterized as having low water application uniformity, especially in windy conditions.

As the water application uniformity of traveler irrigation systems is affected by many factors, a correct combination may provide high values of uniformity, on the other hand, an inappropriate combination may compromise water distribution in the irrigated area by the irrigation system (Hashim et al., 2016; Jangra et al., 2017). Thus, the use of sprinkler simulation models to predict water distribution is an essential tool, when the aim is to optimize the water application uniformity (Rolim \& Teixeira, 2016).

Keller \& Bliesner (1990), considering that gun sprinklers have an almost uniform radial profile, recommend for under very calm wind conditions an irrigation lane spacing of 80 to $90 \%$ of the wetted diameter (WD) and sprinkler sector angles from 210 to $240^{\circ}$. Prado et al. (2012), when studying the theoretical geometric shapes (triangular, elliptical, and uniform) of radial profiles from sprinklers working in traveler irrigation machine systems, found that wetted angles from 240 to $330^{\circ}$ associated with strip spacing between 50 and $80 \%$ of the WD, provided low water application uniformity values.

${ }^{2}$ Universidade Federal de Lavras/ Lavras - MG, Brazil.

Area Editor: Fernando França da Cunha

Received in: 12-11-2019

Accepted in: 5-4-2020 
The outcomes of these works were for sprinkler wetted angles symmetrical to the irrigation travel path. Asymmetric adjustment can be an alternative to improve the water application uniformity for wetted angles between 270 and $330^{\circ}$, associated with larger lane spacings, which reduce the possibility of runoff due to higher water application rates.

Salvatierra-Bellido et al. (2018) pointed out that wind is one of the most relevant factors in sprinkler water distribution. In windy conditions, there is a distortion in the sprinkler water application, resulting in a shortened distribution pattern upwind from the sprinkler, narrowing this pattern at right angles to the wind, and extending the water application pattern downwind. Richards \& Weatherhead (1993) described an empirical procedure to mathematically model the distortion caused by the wind on the water distribution pattern of a gun sprinkler; the use of this model is conditioned to the adjustment of six parameters. To adjust these parameters, it is necessary to perform field water distribution tests in windy conditions with the gun sprinkler working in a stationary way (Prado $\&$ Colombo, 2011) or in a traveler irrigation machine (Smith et al., 2008).

In Brazil, with the use of irrigation systems that work with gun sprinklers, mainly for sugarcane irrigation, there is a demand to develop strategies that aim to improve the water application uniformity of these types of equipment. Adjusting the sprinkler wetted angle asymmetrically to the travel path axis may be a way to improve the water distribution of traveling gun irrigation systems. Thus, this work aimed to simulate the spatial water distribution applied by a gun sprinkler attached in a traveler irrigation machine, working in windy conditions with asymmetric wetted angles, and recommend working conditions that provide suitable water application uniformity values.

\section{MATERIAL AND METHODS}

The work was carried out at the Department of Agricultural Engineering of the State University of Maringá, in Cidade Gaúcha city, Paraná state, Brazil. For the digital simulations of a gun sprinkler attached on a traveler irrigation machine, in wind and no-wind conditions, and working with an asymmetrical sector angle from the oriented line which defines the irrigation travel path, a program was developed in an Excel spreadsheet using the Visual Basic for Applications.

A gun sprinkler installed on a traveler irrigation machine is set to work with a wetted angle $(\theta)$. The adjustment of this wetted angle forms two dry angles, on the left $\left(\alpha_{\mathrm{I}}\right)$ and the right $\left(\alpha_{\mathrm{II}}\right)$ side from the oriented line of the irrigation travel path (Figure 1). Rotating the gun sprinkler wetted circle can also form an asymmetry angle ( $\beta$ ) from the line which sets the travel lane (Figure 1).
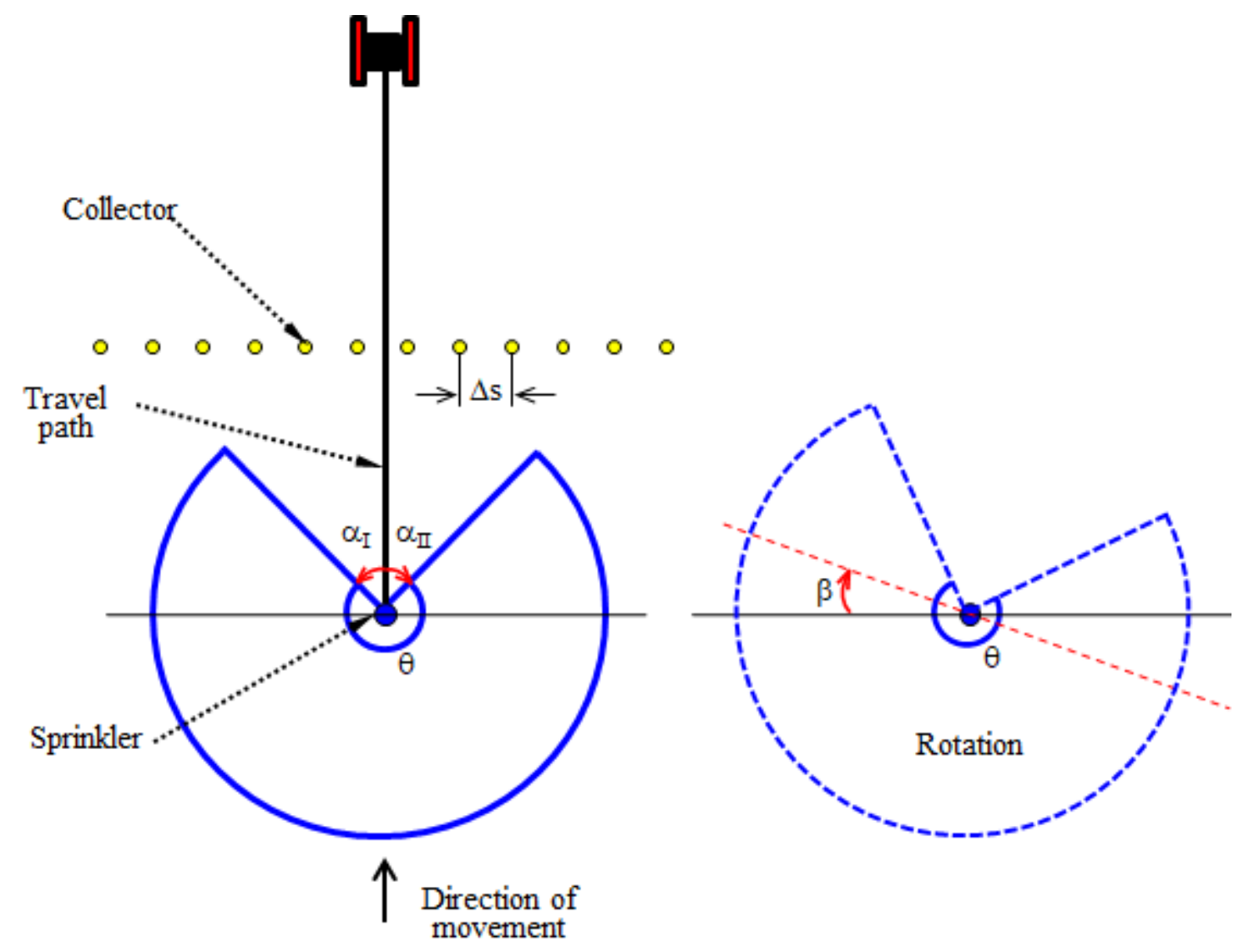

FIGURE 1. Dry angles $\left(\alpha_{\mathrm{I}}\right.$ and $\left.\alpha_{\mathrm{II}}\right)$ set from the travel path and asymmetry angle $(\beta)$ set by the sprinkler wetted circle rotation.

As depicted in Figure 2, the water depth applied by a gun sprinkler working on a traveler irrigation machine, with dry angles $\alpha_{\mathrm{I}}$ and $\alpha_{\mathrm{II}}$, rotation angle $\beta$, and a constant linear speed along the strip, can be computed from the water application rates, caught in a square grid of collectors with the sprinkler located on the center of this grid. This catch grid (Figure 2) is set by a number $(\mathrm{N})$ of water collectors along the axes " $\mathrm{x}_{\mathrm{L}}$ " and " $\mathrm{y}_{\mathrm{L}}$ ". 
To calculate the water application rates in the catch grid (Figure 2) a Cartesian coordinate system $\left(\mathrm{x}_{\mathrm{w}}, \mathrm{y}_{\mathrm{w}}\right)$ from the angle $\delta$ is also set, which represents the angle between the prevailing wind direction and the collector grid $\mathrm{x}_{\mathrm{L}}$-axis.
As shown in Figure 2, in this Cartesian coordinate system $\left(\mathrm{x}_{\mathrm{w}}, \mathrm{y}_{\mathrm{w}}\right)$, the $\mathrm{x}_{\mathrm{w}}$-axis is located on the same line that defines the wind direction and the $\mathrm{y}_{\mathrm{w}}$-axis is located perpendicularly to this line.

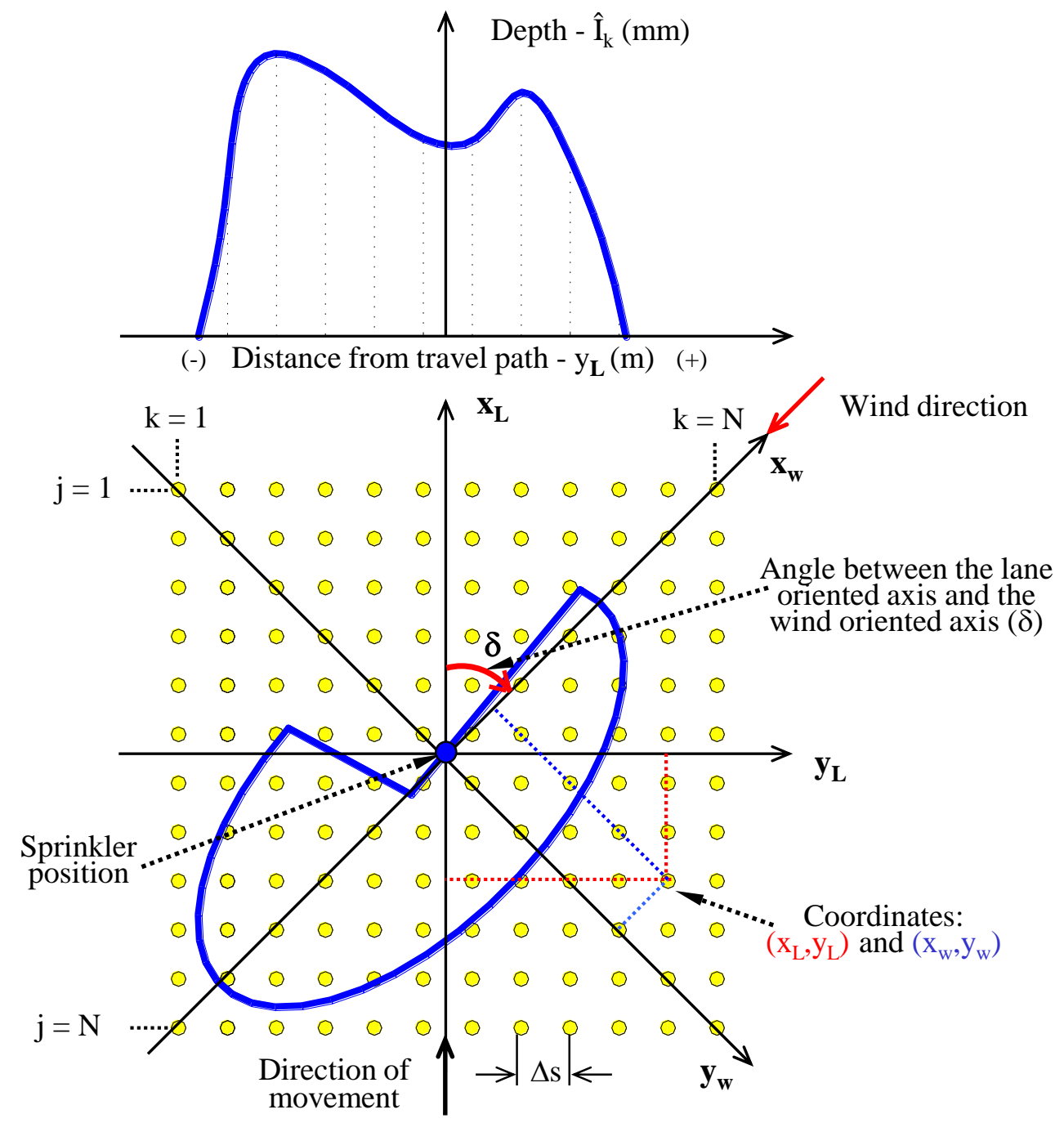

FIGURE 2. Water application depth by a gun sprinkler working in windy conditions and linear speed in the travel path.

According to Prado \& Colombo (2011) and Smith et al. (2008), the semi-empirical model of Richards \& Weatherhead (1993) has been used in the water distribution simulation of gun sprinklers with a good correlation between the estimated and observed values of applied water depth. The coordinates $\mathrm{x}_{\mathrm{w}}$ and $\mathrm{y}_{\mathrm{w}}$ of each collector, in wind conditions, and the parameters (A, B, C, $\mathrm{D}, \mathrm{E}$, and F) of the model of Richards \& Weatherhead (1993) allows interactive computation of the coordinates $\mathrm{x}_{\mathrm{w} 0}$ and $\mathrm{y}_{\mathrm{w} 0}$ for no-wind conditions, by the equations:

$x_{W}=x_{w 0}-\left[A+B \cdot\left(\frac{r}{R}\right)+C \cdot\left(\frac{F}{R}\right)^{2}\right] \cdot v-\left[D \cdot\left(\frac{r}{R}\right)+E \cdot\left(\frac{F}{R}\right)^{2}+F \cdot\left(\frac{F}{R}\right)^{2}\right] \cdot \frac{x_{W D}}{r} \cdot S \cdot w$

$y_{w}=y_{w 0}-\left[D \cdot\left(\frac{r}{R}\right)+E \cdot\left(\frac{r}{R}\right)^{2}+F \cdot\left(\frac{r}{R}\right)^{a}\right] \cdot \frac{y_{w 0}}{r} \cdot S \cdot w$

where: $\quad S=\frac{\sqrt{\operatorname{sen}^{2}(\omega) \cdot x_{w 0}^{2}+y_{w 0}^{2}}}{r}$ and $r=\sqrt{x_{w 0}^{2}+y_{w 0}^{2}}$

In which:

$\mathrm{w}$ - wind speed, $\mathrm{m} \mathrm{s}^{-1}$;

$\mathrm{r}$ - radial distance from the collector to the sprinkler, $\mathrm{m}$;

$\mathrm{x}_{\mathrm{w}}$ and $\mathrm{y}_{\mathrm{w}}-$ coordinates for wind conditions, $\mathrm{m}$; 
$\mathrm{x}_{\mathrm{w} 0}$ and $\mathrm{y}_{\mathrm{w} 0}-$ coordinates for no-wind conditions, $\mathrm{m}$;

$\mathrm{S}$ - sine of the angle between the wind velocity vector and the jet direction of the gun sprinkler;

$\omega$ - sprinkler jet angle, deg;

$\mathrm{A}, \mathrm{B}$, and $\mathrm{C}$ - wind drift constants to be obtained by calibration, $\mathrm{m} \mathrm{m}^{-1} \mathrm{~s}$, and

$\mathrm{D}, \mathrm{E}$, and $\mathrm{F}$ - range shortening constants to be obtained by calibration, $\mathrm{m} \mathrm{m}^{-1} \mathrm{~s}$.

In the sprinkler water distribution curve, the position of each collector to the gun sprinkler $\left(\mathrm{x}_{\mathrm{w} 0}, \mathrm{y}_{\mathrm{w} 0}\right)$ and the sprinkler sector angle adjustment (Figure 1) permit to determine the water application rate in a no-wind condition. Thus, according to the model of Richards \& Weatherhead (1993), applying a correction factor to the water application rate values for a no-wind condition, given by [eq. (3)], it is possible to estimate the water application rate, caught in each collector in the wind condition.

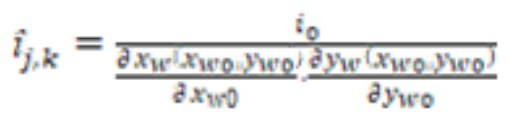

In which:

$\hat{\mathbf{1}}_{\mathrm{j}, \mathrm{k}}$ - application rate estimated from the model, $\mathrm{mm} \mathrm{h}^{-1}$;

$\mathrm{i}_{0}$ - application rate in the no-wind condition, $\mathrm{mm}$ $\mathrm{h}^{-1}$, and

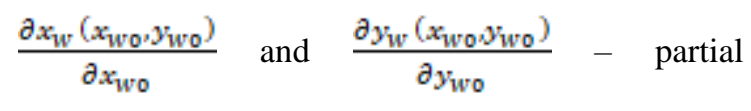

derivatives of eqs (1) and (2).

From the water application rate values applied by a stationary gun sprinkler working in the center of a collector grid, as shown in Figure 2, the water application depth by a moving gun sprinkler can be determined. This procedure is calculated by integrating the water application rate caught in each column of the collector grid by:

$$
\hat{I}_{k}=\frac{\Delta s}{1000-V} \cdot \sum_{j=1}^{N} \hat{l}_{j, k}
$$

In which:

$\hat{\mathrm{I}}_{\mathrm{k}}$ - water application depth by the gun sprinkler along the travel path, $\mathrm{mm}$;

$\Delta \mathrm{s}-$ space between collectors, $\mathrm{m}$, and

$\mathrm{V}$ - travel speed of the water distribution system, $\mathrm{m} \mathrm{h}^{-1}$.

On digital simulations a gun sprinkler moving along the lane (Figure 1) with a constant linear speed of 50 $\mathrm{m} \mathrm{h}^{-1}$, a flow rate of $50 \mathrm{~m}^{3} \mathrm{~h}^{-1}$, and a radius of throw of 42 $\mathrm{m}$ was considered. As pointed out by Prado et al. (2019), the geometric shape of water distribution curves from gun sprinklers, working with a suitable combination of nozzle diameter and pressure, tends to a uniform radial profile. Hence, the water application rate caught in a grid of collectors, as a function of the radial distance of a gun sprinkler with uniform theoretical radial profile, can be computed by:

$$
i(r)=\left\{\begin{array}{l}
\text { for }: 0 \leq r \leq \mathrm{R} \rightarrow \mathrm{i}(r)=\frac{1000 \cdot Q}{\pi \cdot \mathrm{R}^{2}}, \frac{960}{\theta} \\
\text { for } \mathrm{r}>\mathrm{R} \rightarrow \mathrm{i}(r)=0
\end{array}\right.
$$

In which:

$\mathrm{i}(\mathrm{r})$ - water application rate as a function of the radial distance (r) from the sprinkler, $\mathrm{mm} \mathrm{h}^{-1}$;

$\mathrm{r}$ - radial distance from the sprinkler, $\mathrm{m}$;

$\mathrm{Q}$ - sprinkler discharge, $\mathrm{m}^{3} \mathrm{~h}^{-1}$;

$\mathrm{R}$ - radius of throw in a no-wind condition, $\mathrm{m}$, and

$\theta-$ sprinkler wetted angle, deg.

In the simulation running, for the gun sprinkler sector angle adjustment, six wetted angle operations (180, $210,240,270,300$, and $330^{\circ}$ ) for no-wind conditions and three $\left(210,270\right.$, and $\left.330^{\circ}\right)$ for wind conditions were set. The asymmetry angle $(\beta)$ to the irrigation travel path was set by rotating the wetted circle (Figure 1), which ranged from 0 to $90^{\circ}$ with increasing intervals of $5^{\circ}$.

For windy conditions, three wind speeds $(1.5,3.0$, and, $\left.4.5 \mathrm{~m} \mathrm{~s}^{-1}\right)$ and three wind directions $\left(0,45\right.$, and $\left.90^{\circ}\right)$ from the axis that defines the sprinkler trajectory on the lane (Figure 2) were considered. As constants (A, B, C, D, E, and F) of the Richards \& Weatherhead (1993) model, the values obtained by Oliveira et al. (2009), weighted by the radius of throw without wind $\left(\mathrm{A} / \mathrm{R}=0.0362 \mathrm{~s} \mathrm{~m}^{-1} ; \mathrm{B} / \mathrm{R}\right.$ $=0.0131 \mathrm{~s} \mathrm{~m}^{-1} ; \mathrm{C} / \mathrm{R}=-0.0097 \mathrm{~s} \mathrm{~m}^{-1} ; \mathrm{D} / \mathrm{R}=0.0026 \mathrm{~s} \mathrm{~m}^{-1}$; $\mathrm{E} / \mathrm{R}=0.4003 \mathrm{~s} \mathrm{~m}^{-1}$, and $\mathrm{F} / \mathrm{R}=-0.3361 \mathrm{~s} \mathrm{~m}^{-1}$ ), from 53 field tests of a stationary gun sprinkler working under different main nozzle diameters (from 14 to $22 \mathrm{~mm}$ ), working pressures (from 392 to $490 \mathrm{kPa}$ ), and wind conditions (from 0.96 to $5.83 \mathrm{~m} \mathrm{~s}^{-1}$ ) were used.

The water application depths, applied transversely to the sprinkler travel lane (Figure 2), were overlapped simulating an irrigation strip width (L) between 30 to $100 \%$ of the sprinkler WD. The overlapped application depths, for each sprinkler working condition, were used to compute the Christiansen uniformity coefficient (CU).

\section{RESULTS AND DISCUSSION}

Water application profiles transverse to the travel path for no-wind conditions are presented in Figure 3. These profiles were set out to a gun sprinkler working in a traveler irrigation machine with a constant linear speed of $50 \mathrm{~m} \mathrm{~h}^{-1}$, with different adjustments of the wetted sector angle and asymmetry to the travel path. The different profiles depicted in this figure have the same average water application depth.

According to Keller \& Bliesner (1990) and Prado et al. (2012), in transverse profiles of traveling gun irrigation, for symmetrical wetted sector angles to the travel path $(\beta=$ $0^{\circ}$ ) from the sector angle of $180^{\circ}$, stepping up this angle until reaching $270^{\circ}$, there is a better uniformity of the applied water depths along the profile. On the other hand, 
this uniformity is compromised for symmetrical wetted angles of 300 and $330^{\circ}$, resulting in a sharp reduction of the water application depth in the center of the irrigation lane (Figure 3).

Asymmetric adjustment of the sprinkler wetted angle has been recommended for center pivot end-guns (Prado et al., 2019); this procedure leads to the application of a larger amount of water to one side of the irrigation lane (Figure 3). Increasing this asymmetry $\left(\beta=90^{\circ}\right)$ causes a stark reduction in the wetted transverse extension of the gun sprinkler and a rise in applied depth for the wetted sector angles between 180 and $270^{\circ}$. However, this asymmetry keeps almost the same transverse wetted distance and brings a better uniformity of the water application depth, mainly in the center of the irrigation lane, for wetted sector angles of 300 and $330^{\circ}$.
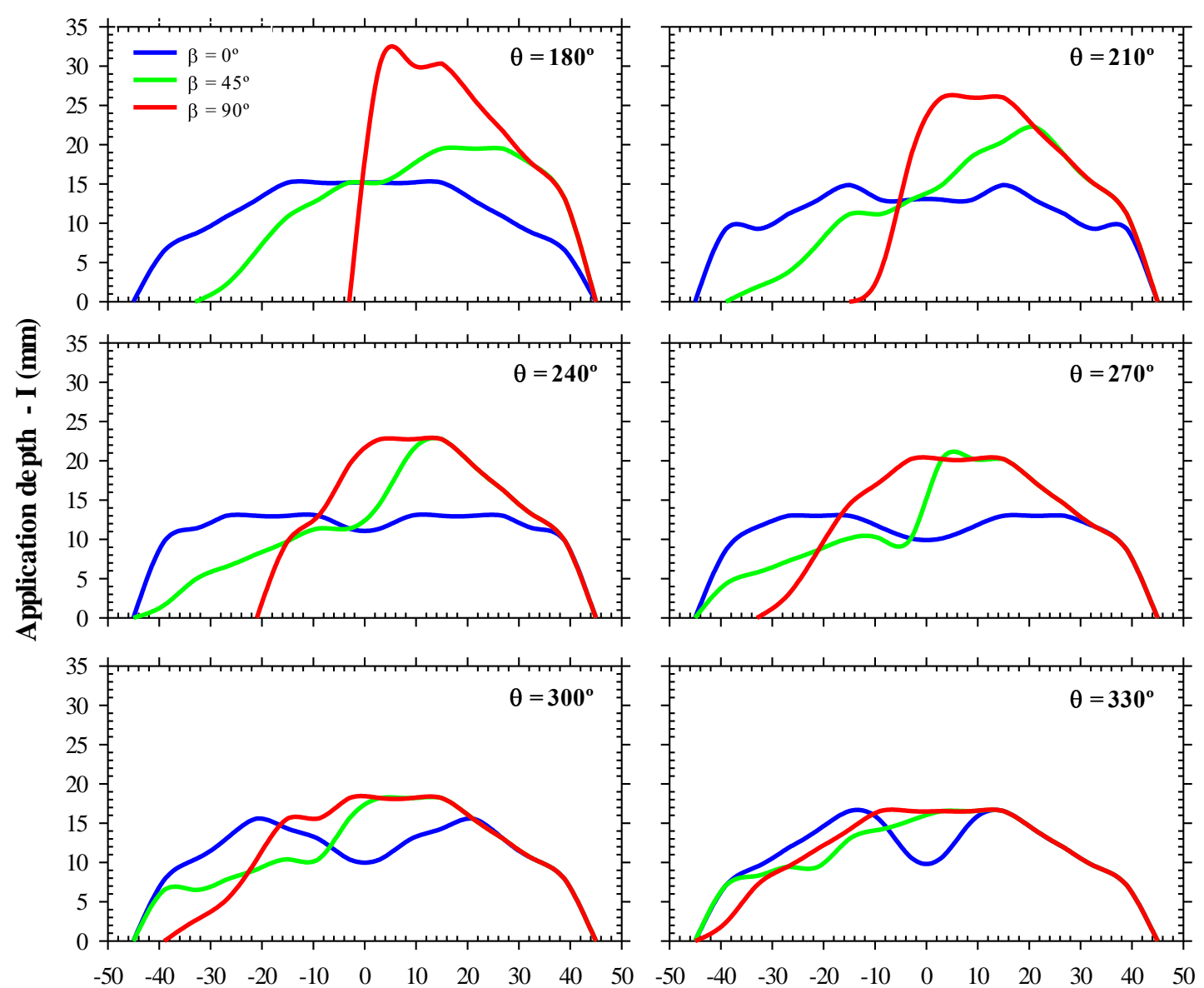

Distance to travel path $(\mathbf{m})$

FIGURE 3. Water application depth profile for a gun sprinkler working in a traveler irrigation machine with a constant linear speed $\left(\mathrm{V}=50 \mathrm{~m} \mathrm{~h}^{-1}\right)$ and no-wind conditions as a function of the wetted sector angle $(\theta)$ and the asymmetry angle $(\beta)$ to the travel path.

The CU for no-wind conditions, simulated from the transverse water depth profiles applied by the sprinkler (Figure 3), are presented in Figure 4. In these simulations, the gun sprinkler working with wetted sector angles from 180 to $330^{\circ}$, asymmetries to the travel path from 0 to $90^{\circ}$, and irrigation lane widths between 30 to $100 \%$ of the sprinkler WD (Figure 4 ) were considered. 


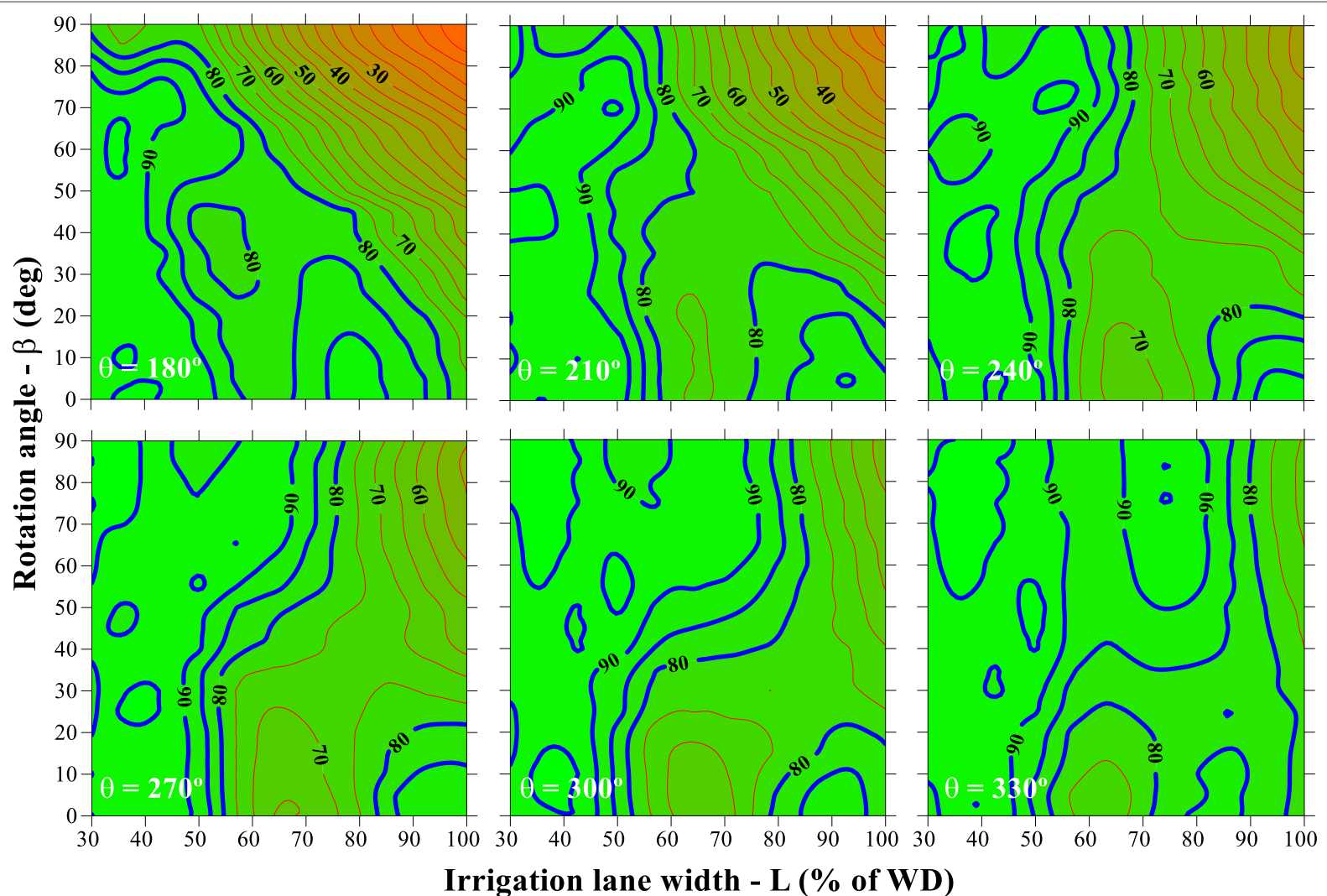

FIGURE 4. Christiansen uniformity coefficient - CU $(\%)$ as a function of irrigation lane width (L) and wetted circle rotation $(\beta)$ for six wetted sector angles $(\theta)$ of the sprinkler (blue lines $-\mathrm{CU} \geq 80 \%$; red lines $-\mathrm{CU}<80 \%$ ).

Irrigation lane widths less than $50 \%$ of the sprinkler WD, regardless of the wetted angle adjustments, provided CU values higher than $80 \%$ for no-wind conditions (Figure 4). Nevertheless, for strip spacings larger than $50 \%$ of the sprinkler WD, some working conditions of the wetted sector angle adjustments led to suitable CU values, while others resulted in uneven water distribution (Jangra et al., 2017). Wider lane spacings should be preferred, on account of decreasing the price to purchase the irrigation system as well as a reduction of labor costs.

Adjusting the sprinkler wetted sector angle to $180^{\circ}$, the symmetry of the angle $(\beta=0)$ to the travel path provides high $\mathrm{CU}$ values, in the range of an irrigation strip width between 30 to $90 \%$ of the WD (Figure 4). This wetted angle adjustment increases the water application rate, which can cause a surface runoff in the case of soils with a low infiltration rate (Maosheng et al., 2018). Asymmetry for the wetted angle of $180^{\circ}$ is not recommended due to the high water application depths to one side of the irrigation lane (Figure 3), which can lead to inappropriate CU values (Figure 4).

As observed by Prado et al. (2012) and presented in Figure 4 , in the strip spacing range (60 to $70 \%$ of the WD) indicated by manufacturers of traveler irrigation machines, sprinkler wetted angles from 210 to $330^{\circ}$, symmetrically adjusted to the travel path $(\beta=0)$, give $C U$ values less than $80 \%$. However, some asymmetry adjustments, especially for wetted angles of 270,300 , and $330^{\circ}$, may considerably increase the CU values (Figure 4).

The geometric shapes of the transverse profiles of water depth applied by the sprinkler moving along the travel path, for asymmetries greater than $30^{\circ}$ with wetted sector angles from 300 to $330^{\circ}$, when overlapping for irrigation strip widths between 30 and $80 \%$ of the WD, result in high uniformity coefficient values ( $\mathrm{CU} \geq 80 \%)$. These wetted sector angle adjustments also lead to lower water application rates provided by sector angles close to $360^{\circ}$ (Rolim \& Teixeira, 2016), but it causes a wetted path along the sprinkler trajectory for rotation angles $(\beta)$ greater than 15 and $30^{\circ}$, respectively, for wetted angles of 330 and $300^{\circ}$.

The CU for the gun sprinkler working under different wind conditions (speed and direction) and wetted sector angles of 210,270 , and $330^{\circ}$ are depicted, respectively, in Figures 5, 6, and 7. As observed in these figures, the increase in wind speed from 1.5 to $4.5 \mathrm{~m} \mathrm{~s}^{-1}$ results in a reduction of water application uniformity (Keller \& Bliesner, 1990). For a wind speed of $4.5 \mathrm{~m} \mathrm{~s}^{-1}$ and parallel to the travel path $\left(\operatorname{dir}=0^{\circ}\right)$, traveling gun irrigation should be avoided since all conditions resulted in a CU less than $80 \%$ (Figures 5, 6, and 7). Differently, in wind directions diagonal $\left(\operatorname{dir}=45^{\circ}\right)$ and perpendicular (dir $=90^{\circ}$ ) to the travel path, respectively, irrigation strip widths about 60 and $70 \%$ of the WD led to a CU greater than $80 \%$ for asymmetries from 0 to $20^{\circ}$, in the wetted angles of 210,270 , and $330^{\circ}$.

Prado et al. (2014) pointed out that wind is one of the main factors affecting water distribution uniformity of sprinkler irrigation systems and for wind speeds higher than $4.0 \mathrm{~m} \mathrm{~s}^{-1}$, sprinkler irrigation should not be employed. Souza et al. (2014), evaluating a sprinkler irrigation system at night and daytime, observed that irrigations during the night are preferred due to lower wind incidence and less water loss. 

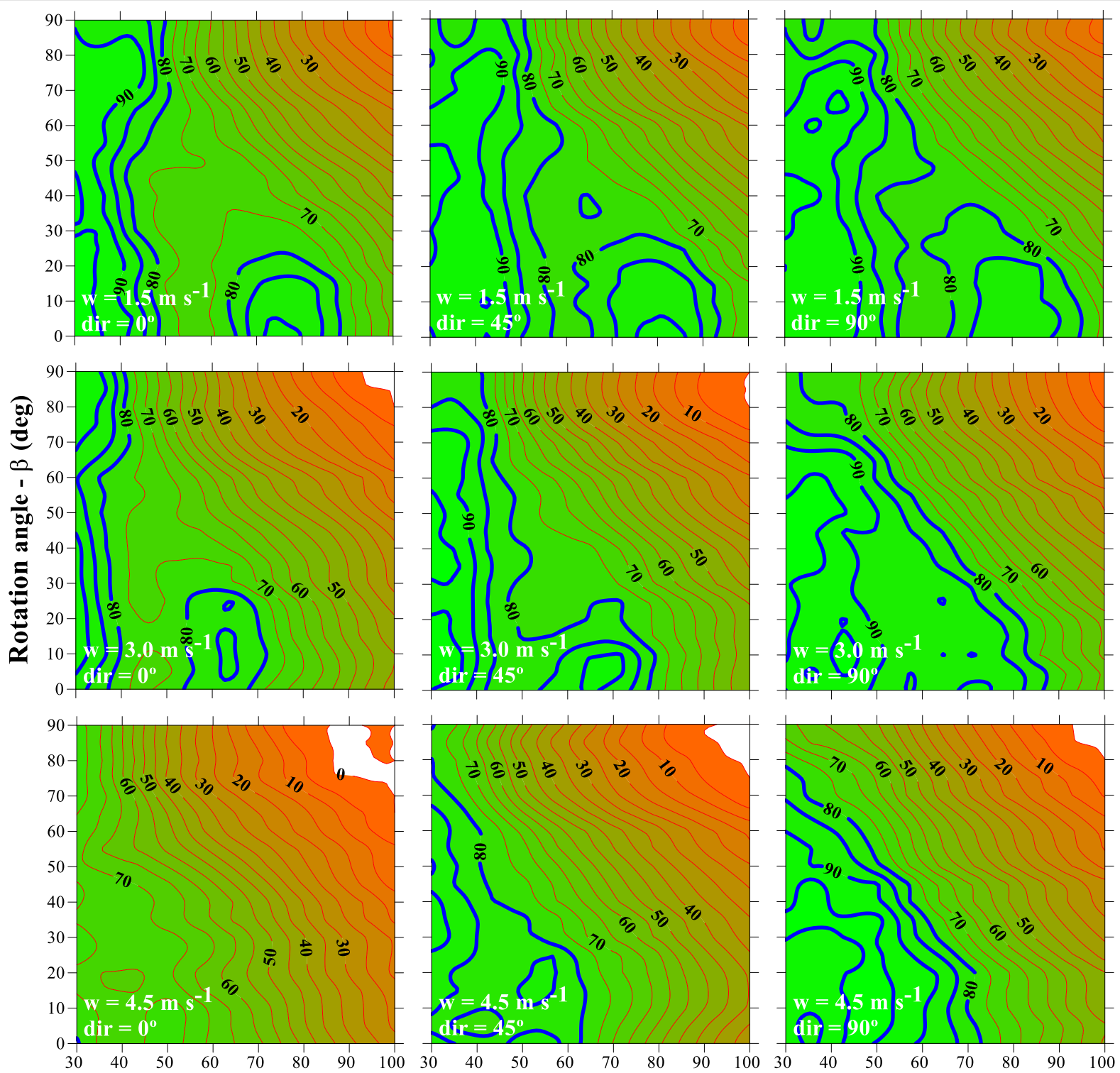

Irrigation lane width - L (\% of WD)

FIGURE 5. Christiansen uniformity coefficient $-\mathrm{CU}(\%)$ as a function of irrigation lane width (L), wetted circle rotation $(\beta)$, wind direction (dir), and wind speed (w) for the wetted sector angle of $210^{\circ}$ (blue lines $-\mathrm{CU} \geq 80 \%$; red lines $-\mathrm{CU}<80 \%$ ).

In circumstances of symmetric wetted angles, irrigation strip widths of $90 \%$ of the WD result in high CU in no-wind conditions, while spacing of about $70 \%$ of the WD provides inadequate $\mathrm{CU}$ for wetted angles between 210 and $330^{\circ}$ (Figure 4). On the other hand, for a wind speed condition of $1.5 \mathrm{~m} \mathrm{~s}^{-1}$, regardless of wind direction, water distribution uniformity improves in the irrigation strip widths around 70\% of the WD (Figures 5, 6, and 7). According to Keller \& Bliesner (1990) and Prado et al. (2012), water application profiles transverse to the travel path with uniform or rectangular shapes result in high $\mathrm{CU}$ values for spacings near the WD for no-wind conditions. 

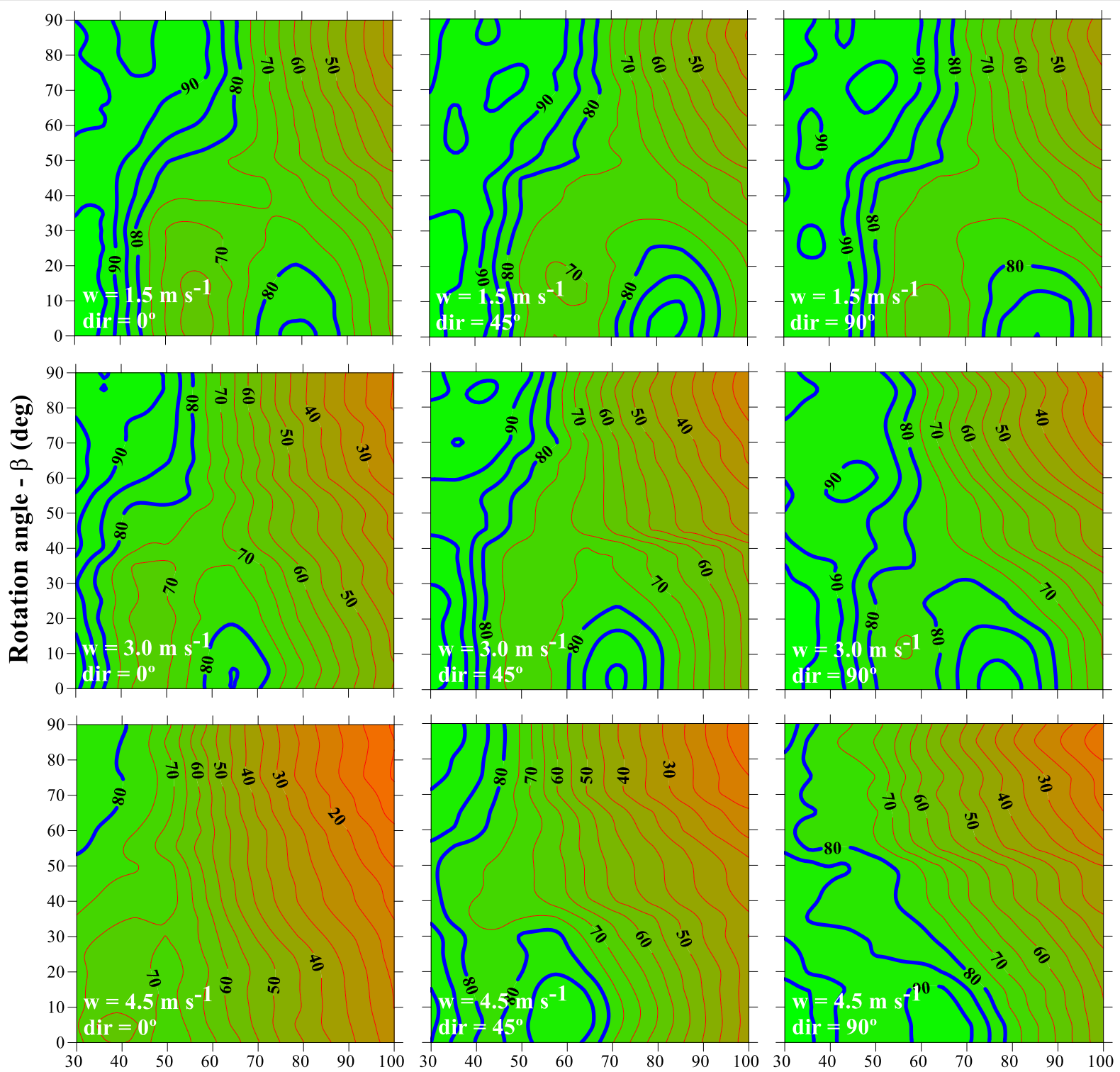

Irrigation lane width - L (\% of WD)

FIGURE 6. Christiansen uniformity coefficient - CU (\%) as a function of irrigation lane width (L), wetted circle rotation $(\beta)$, wind direction (dir), and wind speed (w) for the wetted sector angle of $270^{\circ}$ (blue lines $-\mathrm{CU} \geq 80 \%$; red lines $-\mathrm{CU}<80 \%$ ).

The outcomes of CU for symmetrical angles, working under a wind speed of $3 \mathrm{~m} \mathrm{~s}^{-1}$ and perpendicular to the travel path direction $\left(\operatorname{dir}=90^{\circ}\right)$, showed greater values than the diagonal $\left(\operatorname{dir}=45^{\circ}\right)$ and parallel $\left(\operatorname{dir}=0^{\circ}\right)$ directions (Figures 5, 6, and 7). Travel lanes parallel to the prevailing wind direction must be avoided, once the transversal water application profiles have a poor overlap; as a result, the CU values decrease (Keller \& Bliesner, 1990; Shull \& Dylla, 1976). Lane spacings about 70 and $80 \%$ of the WD, respectively, for perpendicular and diagonal wind direction, result in a CU greater than $80 \%$ for the symmetrical wetted angles of 210,270 , and $330^{\circ}$. 

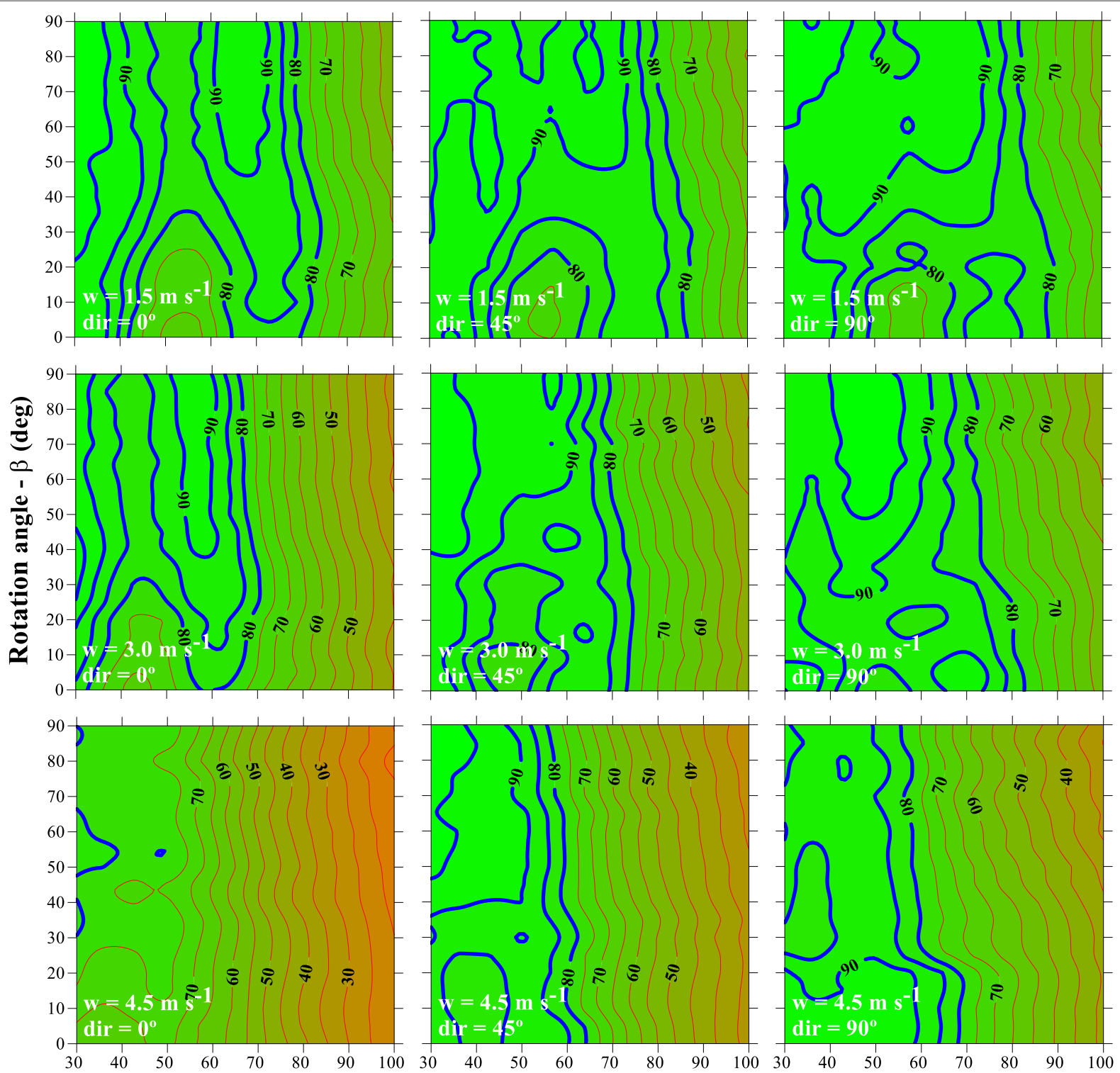

Irrigation lane width - L (\% of WD)

FIGURE 7. Christiansen uniformity coefficient - CU (\%) as a function of irrigation lane width (L), wetted circle rotation $(\beta)$, wind direction (dir), and wind speed (w) for the wetted sector angle of $330^{\circ}$ (blue lines $-\mathrm{CU} \geq 80 \%$; red lines $-\mathrm{CU}<80 \%$ ).

As observed in Figures 5 and 6, asymmetric adjustments in the wetted angles of 210 and $270^{\circ}$ can reduce the $\mathrm{CU}$ values, contrarily for the wetted angle of $330^{\circ}$, asymmetries between 15 and $20^{\circ}$ can improve the water distribution of traveler irrigation systems (Figure 7). Shull \& Dylla (1976) mention that water application uniformity must remain stable for wind and no-wind conditions. Thus, a wetted angle of about $330^{\circ}$, combined with an asymmetry of $15^{\circ}$, and lane spacing between 60 and $70 \%$ of the WD can result in high CU values.

The outcomes presented are suitable for any gun sprinkler which has a stationary radial curve near the uniform or rectangular shape. Prado et al. (2007), testing a large gun sprinkler working with nozzle diameters from 34 to $44 \mathrm{~mm}$, working pressure between 392 and $580 \mathrm{kPa}$, observed discharges from 84 to $168 \mathrm{~m}^{3} \mathrm{~h}^{-1}$ and water curves with a doughnut shape in the aforementioned conditions. Therefore, studies regarding asymmetric wetted angles could be a possibility to improve the water distribution of gun sprinklers which have a water curve with an irregular shape.

\section{CONCLUSIONS}

In windy conditions, irrigation strip widths between 60 and $70 \%$ of the WD are suitable for traveler gun irrigation systems;

For sprinkler wetted sector angles of less than $270^{\circ}$, the use of asymmetrical angles decreased the water application uniformity, mainly in windy conditions;

Wetted sector angles close to $330^{\circ}$, associated with asymmetrical adjustments, provided adequate values of water application uniformity for any wind condition.

\section{REFERENCES}

ANA - Agência Nacional de Águas (2017) Atlas irrigação: uso da água na agricultura irrigada. ANA, 86p.

Darko RO, Shouqi Y, Junping L, Haofang Y, Xingye Z (2017) Overview of advances in improving uniformity and water use efficiency of sprinkler irrigation. International Journal of Agricultural and Biological Engineering 10(2):1-15. DOI:

http://dx.doi.org/10.3965/j.ijabe.20171002.1817 
Hashim S, Mahmood S, Afzal M, Azmat M, Rehman HA (2016) Performance evaluation of hose-reel sprinkler irrigation system. Arabian Journal for Science and Engineering 41(10):3923-39030. DOI: http://dx.doi.org/10.1007/s13369-015-1953-x

Jangra P, Jhorar RK, Kumar S, Kamra SK (2017) Performance evaluation of traveler irrigation system. Irrigation and Drainage 66:173-181. DOI: http://dx.doi.org/10.1002/ird.2097

Keller J, Bliesner RD (1990) Sprinkle and trickle irrigation. New York, Springer, 652p.

Leda VC, Gonçalves AK, Lima NS (2019) Sensoriamento remoto aplicado a modelagem de produtividade da cultura da cana-de-açúcar. Energia na Agricultura 34(2):263-270. DOI: http://dx.doi.org/10.17224/EnergAgric.2019v34n2p263-270

Maosheng G, Pute W, Delan Z, Lin Z (2018) Analysis of kinetic energy distribution of big gun sprinkler applied to continuous moving hose-drawn traveler. Agricultural Water Management 201:118-132. DOI: https://doi.org/10.1016/j.agwat.2017.12.009

Oliveira HFE, Colombo A, Faria LC (2009) Modelagem dos efeitos do vento sobre as dimensões do alcance do jato de um canhão hidráulico. Revista Brasileira de Engenharia Agrícola e Ambiental 13:818-824. DOI: http://dx.doi.org/10.1590/S1415-43662009000700002

Oliveira HFE, Colombo A, Faria LC, Prado G (2012) Efeitos da velocidade e da direção do vento na uniformidade de aplicação de água de sistemas autopropelidos. Engenharia Agrícola 32(4):669-678. DOI: http://dx.doi.org/10.1590/S0100-69162012000400006

Prado G (2016) Water distribution from medium-size sprinkler in solid set sprinkler systems. Revista Brasileira de Engenharia Agrícola e Ambiental 20(3):195-201. DOI: http://dx.doi.org/10.1590/1807-1929/agriambi.v20n3p195-201

Prado G, Colombo A (2011) Ajuste de parâmetros para distorção da distribuição de água aplicada por canhões hidráulicos em condições de vento. Irriga 16(1):52-69. DOI: https://doi.org/10.15809/irriga.2011v16n1p52

Prado G, Colombo A, Barreto AC (2014) Distorção da distribuição de água aplicada por sistemas autopropelidos de irrigação em condições de vento. Irriga 19(3):358-374.

Prado G, Colombo A, Barreto AC (2019) Water distribution model for center pivot end gun sprinklers. Revista Brasileira de Engenharia Agrícola e Ambiental 23(7):477-483. DOI: http://dx.doi.org/10.1590/18071929/agriambi.v23n7p477-483
Prado G, Colombo A, Biagioni PF (2007) Ângulo de giro e espaçamento entre carreadores em sistemas autopropelidos de irrigação com o aspersor Plona-RL400. Revista Brasileira de Engenharia Agrícola 27(2):346-353. DOI: http://doi.org/10.1590/S0100-69162007000300003

Prado G, Colombo A, Oliveira HFE, Faria LC (2012) Uniformidade de aplicação de água de equipamentos autopropelidos de irrigação com aspersores de perfil radial triangular, elíptico e retangular. Engenharia Agrícola 32(3):522-529. DOI: http://dx.doi.org/10.1590/S010069162012000300011

Richards PJ, Weatherhead EK (1993) Prediction of raingun application patterns in windy conditions. Journal Agricultural Engineering Research 54:281-291.

Rolim J, Teixeira JL (2016) The design and evaluation of travelling gun irrigation systems: erolador software. Engenharia Agrícola 36(5):917-927. DOI: http://dx.doi.org/10.1590/1809-4430-

Eng.Agric.v36n5p917-927/2016

Salvatierra-Bellido B, Montero-Martínezb J, PérezUrrestarazuc L (2018) Development of an automatic test bench to assess sprinkler irrigation uniformity in different wind conditions. Computers and Electronics in Agriculture 151:31-40. DOI:

https://doi.org/10.1016/j.compag.2018.05.036

Shull H, Dylla AS (1976) Traveling gun application uniformity in high winds. Transactions of the ASAE 19(2):254-258. DOI: http://dx.doi.org/10.13031/2013.36007

Silva S, Dantas Neto J, Teodoro I, Souza JL, Lyra GB, Santos MAL (2015) Demanda hídrica da cana-de-açúcar irrigada por gotejamento nos tabuleiros costeiros de Alagoas. Revista Brasileira de Engenharia Agrícola e Ambiental 19(9):849856. DOI: http://dx.doi.org/10.1590/18071929/agriambi.v19n9p849-856

Silva LL, Serralheiro R, Santos N (2007) Improving irrigation performance in hose-drawn traveller sprinkler systems. Biosystems Engineering 96(1):121-127. DOI: http://dx.doi.org/10.1016/j.biosystemseng.2006.10.004

Smith RJ, Gillies MH, Newell G, Foley JP (2008) A decision support model for travelling gun irrigation machines. Biosystems Engineering 100(1):126-136. DOI: https://doi.org/10.1016/j.byosystemseng.2008.01.004

Souza JM, Pereira LR, Reis EF, Teixeira AG, Rafael AM, Cruz EA (2014) Desempenho de um sistema de irrigação por aspersão durante os períodos diurno e noturno na região sul do Espírito Santo. Revista Agroambiente 8(3):416-423. DOI: http://dx.doi.org/10.5327/Z 19828470201400031856 